\title{
REGRESION MODELS FOR ASSESMENT OF THE VOLUME INCREMENT OF THE FIR, BEECH AND SPRUCE IN FORESTS OF BEECH, FIR AND SPRUCE ON LIMESTONE IN FEDERATION OF BOSNIA AND HERZEGOVINA
}

Regresioni modeli za procjenu zapreminskog prirasta jele, bukve i smrče u šumama bukve i jele sa smrčom na krečnjacima u Federaciji Bosne i Hercegovine

\begin{abstract}
Ahmet Lojo ${ }^{1}$

The paper displays research results of volume increment size of main tree species, fir, beech and spruce within mixed forests of beech, fir and spruce on limestone and dolomites in Federation of Bosnia and Hercegovina ( $\mathrm{FBiH})$.

Fir and beech forests along with the spruce represent the most important part of forest resources in $\mathrm{BiH}$. As LOJO (2013) points out, around 371000 ha of these forests are located on limestone and dolomites and are selection forests for the most part. Knowledge of laws of changes in size of volume increment of selection stand of trees is necessary for high quality planning of forestry production. The paper explores changes of volume increment sizes especially for following tree species: fir, spruce and beech within mixed stand of trees. Research sample are measured sample plots from 799 mixed stand of trees larger than 40 ha recorded during 11 years' time during the creation of forest management plans. Stands of trees in which control recordings were conducted for the purpose of reliability of data were taken as a sample. Multiple regression models for estimation of volume increment size of fir, spruce and beech including two models for each species of trees. Models used for volume increment size estimation of mixed forest in optimal - normal state and models used for determination of volume increment that is as accurate as possible when the size of multiple independent factors that affect change in volume increment size are known. This paper explores dependence of change of volume increment on: site class expressed through average height of trees whose diameter is $50 \mathrm{~cm}$, share of species of trees in the stand volume, degree of coverage of the ground with crowns of trees of medium diameter in stand of trees which was calculated based on the basal area of species of trees and share of deciduous trees in the stand of trees volume. For more precise model size of basal area of species of trees in stand of trees and average altitude were used.
\end{abstract}

Key words: Volume increment, yield, unevenaged (irregular) mixed forest of fir, spruce and beech

\footnotetext{
${ }^{1}$ Faculty of Forestry, University of Sarajevo, Bosnia and Herzegovina
} 


\section{INTRODUCTION - Uvod}

Knowledge of laws in change of size of volume increment of stands of trees is one the basic conditions for production planning in forestry. Volume increment is the most important indicator of yield and a necessary condition for objective estimation of normal $^{2}$ sizes and structures of forests and stands of trees i.e. it is a condition for making objective forest management plans.

When we talk about productivity of some mixed stand of trees where trees are of different age we can talk about the current productivity of the stand of trees. Current productivity of the stand of trees is reflected in the size of current stand of trees which, along with the factors on which man cannot make any impact, depends on the current structure and size of the volume of the tree stand, on the participation of individual species of trees, on volume arrangement to the tree tapers i.e. on number of trees per tree tapers, degree of coverage of the ground with crowns of trees...

Current productivity is reflected in the size and quality of the yield of trees that currently can be achieved from the tree stand along with maintenance of its existing structure and volume size.

Potential productivity is mostly unknown, it cannot be directly measured within short time period and we are trying to define it through the ideal shape of the tree stand, i.e. we are trying to reach an answer how what will be the size of current volume increment when the tree stand is made to be in optimal-normal shape.

On the other hand normal shape of the tree stand does not have to be the one where the biggest volume increment is temporarily achieved. Selection stand of trees is in normal shape when it permanently produces yield which is in the best accordance with the society's needs (MATIĆ, 1963) along with continual regeneration of the stand of trees with plentiful and healthy offspring.

Such yield has appropriate structure of number of tress per tree tapers (different for individual site class and for each type of trees) and a certain structure of volume of stand of tree is necessary for its production. Such volume does not necessarily have to produce the biggest volume increment too but yield per the amount must be equal to the volume increment in size. Setting out from the structure of desired yield, in order to achieve the size and structure of the volume that can produce it, it is necessary to assume in advance i.e. determine the total size of volume increment of the stand of trees, how big will it be when we get the stand of trees to the normal state.

All forests within some forest management area for which we determine medium term management plan (forest management plan) are divided to management classes. A management class is a basic managerial unit of forests for planning and control of forest management. (BiH linguistic term MATiĆ, 1965, 1977) It encompasses stands of trees of nearly the same ecologically productive characteristics for which one technical goal of management can be planned. It means that within

2 "Normal volume" - term meaning the ideal state of structure and size of volume of forest 
management plan of forest management for some management class biotechnical measures unique for all tree stands that compose it are planned. Inter alia technical goal means defining "normal state of the forest" too. Normal shape of the forest (size and structure of the volume) has an inevitable, important role during determining of the volume of felling for the following managerial period for which plans of forest management are determined.

Thus knowledge of current and potential productivity of stands of trees is a precondition for their high quality distribution to different management classes.

Fir and beech forests along with the spruce represent the most important part of forest resources in $\mathrm{BiH}$. According to LOJO $(2011,2013)$ around 371000 ha of these forests are located on limestone and dolomites and are selection forests for the most part and are state-owned $(92 \%)$

During $50 \mathrm{~s}, 60 \mathrm{~s}$ and $70 \mathrm{~s}$ of the last century large researches of increment and yield of our stands of trees were initiated for economically most important species of trees in Bosnia.

Those researches first started within selection forests of beech and fir with spruce (MATiĆ, 1959).

Matić conducted researches of sizes of taxation elements of selection forests (mixed and pure) of spruce and beech at the area of Bosnia. Based on the data collected from 383 temporary experimental plots within these forests from 1952 to 1958, he conducted large analysis of laws of changes in sizes of main taxation elements (measurement characteristics) of selection forests using methods of regression analysis. Results of those researches are represented in tables (MATIC et al 1963; DRINIĆ et al,1980, 1990).

These forests were subject of research of increment and yield in this paper, but it refers only to their part located on limestone and dolomites.

\section{THE GOAL OF PAPER - Cilj istraživanja}

In order to resolve the question of normal composition of mixed selection beech, for and spruce forests and for the need of estimation of sizes of volume increment of main species of trees in them, as a goal of this paper it was necessary to find equations for estimation of sizes of volume increment (models) namely models for explanation of impact of individual (main) independent factors to the dependent quantity in which as influential factors are only variables which are also mutually independent for the most part and whose measures can be defined as "normal" in advance.

\footnotetext{
${ }^{3}$ The paper is excerpt of the part of defended $\mathrm{Ph}$. D. theses of A. Lojo from 2011 under the name: Forming of management classes within beech, fir, and spruce forests on limestone and dolimites
} 


\section{MATERIAL AND METHODS OF RESEARCH - Materijal i metode istraživanja}

Depending on other measurable factors in the stand of trees, it is necessary to research the change of sizes of annual volume increment in the stand of trees for each of the main tree species individually.

In order to determine the size of current volume increment of individual species of trees from other measurable factors within the stand of trees it is necessary to first determine what are measurable factors within the stand of trees and that have a significant impact on the change of size of volume increment of individual species of trees in the stand of trees. Furthermore, it is necessary to find an adequate regression model of impact of those factors to the size of volume increment as dependent variable.

Sample

In order to achieve the purpose of this paper the collected data on selection stand of trees within mixed beech and fir and fir with spruce and fir and spruce forests. The data were obtained via forest inventories in 11 forest management plans (FMP) in $\mathrm{FBiH}$ who were then selected, analysed and processed at the level of individual stands of trees. Taxation recordings in these areas were conducted in the period 2000-2005. From the data on taxation data recording relating to the aforementioned tree stands, 799 of them, were isolated and unified in unique data base. All the tree stands were larger than 40 ha and of unified orthographic characteristics (LOJO, 2010, 2013).

\section{The procedure of determining of models and influential factors}

Volume increment in the stand of trees depends on the larger number of factors which display their influence regardless of the influence of other factors or they can have interactive impact to the size of volume increment with some other independent factor.

Scientific tool that is at our disposal for solving these tasks are multivariate analysis of variance and regression (HADŽiVUKOVić, 1973).

From the previous research (MATIĆ, 1959, 1980; DRINIĆ, 1972; BOZALO, 1980; BURGER, 1951, 1952, 1953) of these problems one can assume that the most influential taxation element by which for the most part we can explain the change in size of current volume increment of some types of trees in the stand of trees, its basal area in the stand of trees or volume of trees of the contemplated species of trees.

However, in order to estimate the size of volume increment of some species of trees in "normal stand of trees" we are not familiar with the basal area nor with volume of species of trees in the stand of trees in advance.

It is necessary to find a regression model for determining of volume increment of spruce or beech, in mixed stand of trees of beech and fir with spruce based on those taxation elements whose size we can in advance assume to be "normal".

That is certainly site class for the growth of species of trees expressed relatively or via height of the trees whose diameter is $50 \mathrm{~cm}$, share of species of trees in the volume of the increment, medium diameter of the tree of the considered species of trees in the 
stand of trees and the degree of coverage of the ground with crowns of tree. Among these elements we can include shares of other species of trees in the stand of trees too. In order to apply the procedure of multiple linear regression in seeking optimal model of regression equation, certain preconditions must be fulfilled in order to make the procedure correct:

1. Variables (predictors) taken into the equation must be mutually independent;

2. Variables must have distribution of their physical quantities that are of approximately normal distribution;

3. In order to estimate the significance of the impact of each individual predictor to the dependent variable their variances as well as the variance of dependent variable should be unified i.e. a condition of homogeneity of the variances;

4. Impact of each independent variable to the dependant variable is linear

If these conditions are not fulfilled, if we analyse original sizes of variables then it is necessary to use adequate transformation and recalculate them to the form which is eligible for calculating parameters using the method of multiple regression.

Since this is a problem that is solved using the methods of multivariate analysis using larger number of continuous variables where the impacts of individual independent variables in interaction with others can appear important it was necessary to do certain transformation of independent variables (linearize the impact to the dependent variable) and standardize them. In such way a problem of collinearity of individual components - individual independent variables and their products with other independent variables.

In order for the analysis to be conducted in a proper manner the variables must be previously transformed and standardized or just standardized if their impact is approximately linear to the dependent and if the distribution of their variables is approximate to the normal arrangement. Standardisation is conducted according to the following formula:

$$
x_{s t}=\frac{x_{i}-\bar{x}}{s_{x}}
$$

Where: $X_{s t}$ - standardized size of the variable,

$X_{i}$ - original size of the variable,

$\bar{X}$ - average size of the variable $X$,

$s_{x}$ - standard deviation of variable $X$.

If the variables are expressed in percentile rank and contain significant data structure deviation from the normal function they should be previously normalized by transformation according to some eligible formula. If it is about the right skewed distribution of sizes the following formula can be applied:

$$
x_{T}=\arcsin \frac{x}{100}
$$


If it is about the left skewed distribution of data the following formula is applicable:

$$
x_{T}=\sqrt{x} ;
$$

where: $X$ - original size, and $X_{T}$ - transformed size of the variable.

\section{RESULTS - Rezultati istraživanja}

Size of current volume increment of individual species of trees in the stand of trees depending on other taxation elements of the stand of trees

\section{Size of current volume increment of fir part of stand of trees depending on other taxation elements of the stand of trees}

In solving the first task of the goal of the paper, seeking for optimal regression model of the equation based on which we can evaluate potential productivity of fir in the stand of trees only those elements whose sizes can be assumed as "normal" were chosen to be independent variables.

Those are:

- site class for fir expressed through average height of the trees whose diameter is $50 \mathrm{~cm}\left(\mathrm{H} 50 \_\mathrm{Jl}\right)$, share of fir in the volume of the stand of trees (OS_Jl),

- degree of coverage of ground with crowns of trees above the taxation threshold of $5 \mathrm{~cm}(\mathrm{STZ})$

- medium diameter of fir trees in the stand of trees is calculated based on the basal area $\left(\mathrm{Dg} \_\mathrm{Jl}\right)$ and,

- share of deciduous trees in the volume of the stand of trees (ratio of the mixture) (OS L).

Namely, it is familiar from earlier research on the subject of normal composition of selection stand of trees in Bosnia (MATIĆ, 1963) that normal stands of trees on different site classes have different sizes of basal area, reserves, medium diameter and in order to enable continual regeneration of the stand of trees via natural offspring the degree of coverage of the land with crowns of trees above taxation threshold cannot be complete but it can be bigger in stands of trees on better habitats. These variables could not be in a relationship that is mutually correlated or at least not so outstanding that the impact of each of variables to the dependent variable is not expressed mathematically in its essence i.e. on can assume that any of those 5 variables can vary free within their domain and that the rest of the variables are not changed. We cannot affect the site class of the habitat with our usual forest activities but sizes of other taxation elements can be regulated. If we do not include the basal area as influential factor to our regression equation which is, besides, in the biggest correlation with the size of volume increment, then that factor which is not 
encompassed should be expressed through site class of the habitat - i.e. the average height of trees that are $50 \mathrm{~cm}$ thick and through a share of species of trees in the stand of trees whose volume increment we are estimating and of course partially through the degree of coverage of ground with crowns of trees.

By inclusion of variable of share of deciduous trees in the volume of the stand of trees (OS_L) to regression equation we get the possibility to, along with the share of fir in the volume of the stand of trees, at the same time define the ratio of spruce and other deciduous trees which are mostly made of beech.

At the same it is perfectly clear that with the change of site class of the habitat for one site class the absolute difference in the size of volume increment of fir in the stand of trees in case when its share in the stand of trees are $20 \%$ and when its share is $40 \%$ or some other. It is the same with other variables (Dg-Jl i STZ). It means that classic regression model with just additional impacts of individual variables cannot provide a high quality solution of the equation whose error of the estimate of dependent variable could be satisfying - unified in the whole domain of variability in the dependent variable.

For quality solution a new model of multiple - factor regression must be set in which products of independent variables as additional influential factors.

\section{Models of regression equations for the estimation of volume increment of fir in the stand of trees}

\section{Regression model 1}

During the determination of regression models for the estimate of size of volume increment in the first step, through the procedure of factor regression (GRM module of program STATISTICA 7.0), an optimal set of independent variables and their interactions was determined and after that in program "STATGRAPHIC“ an optimal transformation of dependent variable was determined because of the homogenization of the variable of the residual.

Out of 799 stands of trees the sample contained 783 mixed stands of trees in which fir was present. Basic data on the sizes of chosen variables in the first regression model for fir (regression model 3) are given in the table 1.

In order to fully enable high quality calculation of the significance of individual parameters along with the independent variables or their products through the procedure of multiple linear regression or factorial regression - forward procedure, it is necessary to transform the variables so that their distribution is normal or that it aspires to it, if that is not the case with the original measures. Also variables are necessary to be standardized in order to avoid the problem of collineraity of the equation parameter. 
Table 1. Markers, meaning and basic statistical indicators of variables from 783 stands of trees containing fir

Tabela 1. Oznake, značenje i osnovni statistički pokazatelji varijabli iz 783 sastojina u kojima učestvuje jela

\begin{tabular}{|c|l|c|c|c|c|c|}
\hline $\begin{array}{c}\text { Variable } \\
\text { (Code) }\end{array}$ & \multicolumn{1}{|c|}{ Name of the variable } & $\begin{array}{c}\text { Physica } \\
1 \\
\text { quantity }\end{array}$ & $\bar{x}$ & Sx. & Min. & Max. \\
\hline Ivha_J1 & $\begin{array}{l}\text { Current volume increment of } \\
\text { fir }\end{array}$ & $\mathrm{m}^{3} / \mathrm{ha}$ & 3,529 & 2,271 & 0,002 & 16,05 \\
\hline H50_J1 & $\begin{array}{l}\text { Average height of fir tree } \\
\text { whose diameter is } 50 \mathrm{~cm}\end{array}$ & $\mathrm{~m}$ & 27,00 & 2,345 & 19,94 & 33,74 \\
\hline STZ & $\begin{array}{l}\text { Degree of coverage of ground } \\
\text { with crowns of trees }\end{array}$ & $\%$ & 86,93 & 12,35 & 32,62 & 100,0 \\
\hline OS_J1 & $\begin{array}{l}\text { Share of fir in the volume of } \\
\text { tree stand }\end{array}$ & $\%$ & 38,99 & 19,88 & 0,06 & 99,33 \\
\hline Dg_J1 & Medium diameter of fir & $\mathrm{cm}$ & 24,94 & 7,72 & 7,00 & 65,06 \\
\hline OS_L & $\begin{array}{l}\text { Share of deciduous trees in the } \\
\text { volume of the volume of stand } \\
\text { of trees }\end{array}$ & $\%$ & 43,176 & 25,87 & 0,00 & 99,0 \\
\hline
\end{tabular}

Variable STZ - degree of coverage of ground with crowns of trees is first transformed using the equation:

$\operatorname{asin}(S T Z / 100)=\arcsin \frac{S T Z}{100}$, then those sizes were standardized according to the formula: $x_{s t}=\frac{x_{i}-\bar{x}}{s_{x}}$, using average sizes and standard deviation of the variable asinSTZ/100 (table 2).

Also variable $\mathrm{Dg} \_\mathrm{J} 1$ - Medium diameter of fir was first transformed using the equation: $x_{T}=\sqrt{x}$; i.e. the root was taken from the original sizes and then standardized using the formula $x_{s t}=\frac{x_{i}-\bar{x}}{s_{x}}$. Other variables were just standardized using the previous formula.

Table 2. Marks of original and transformed variables and basic statistical indicators of variables from 783 stands of trees containing fir

Tabela. Oznake originalnih i transformisanih varijabli i osnovni statistički pokazatelji varijabli iz 783 sastojine u kojima učestvuje jela

\begin{tabular}{|c|l|c|l|c|c|}
\hline $\begin{array}{l}\text { Mark of } \\
\text { the } \\
\text { variable }\end{array}$ & $\begin{array}{c}\text { Marks of the transformed } \\
\text { variables }\end{array}$ & $\bar{x}$ & Sx. & Min. & Max. \\
\hline \hline \multirow{2}{*}{ STZ } & asin (STZ/100) & 1,11730 & 0,33223 & 1,5708 & 0,26012 \\
\cline { 2 - 6 } & ASIN STZ & 0,00000 & $-3,01816$ & 1,7434 & 1,00000 \\
\hline OS_Jl & OS_Jl-st & 0,00000 & $-1,95779$ & 3,0350 & 1,00000 \\
\hline OS-L & OS-L-st & $-0,00000$ & $-1,66901$ & 2,1943 & 1,00000 \\
\hline H50_Jl & H50-Jl-st & 0,00000 & $-3,01168$ & 2,8729 & 1,00000 \\
\hline \multirow{2}{*}{ Dg_Jl } & SQ_Dg_Jl & 4,93628 & 2,64575 & 8,0658 & 0,76289 \\
\cline { 2 - 6 } & SQ_Dg_J1_st & 0,00000 & $-3,00245$ & 4,1023 & 1,00000 \\
\hline
\end{tabular}


After transformations all variables satisfy the normality test and have uniform variances, so all the conditions are fulfilled for regression to be conducted, i.e. to determine statistically significant factors to the quantity Ivha J1 and calculation of parameters of the equation. Main statistical indicators on transformed independent variables are depicted in the table 2 .

Since sizes of dependent variables too did not have normal arrangement of their sizes, dependent variable was previously transformed in the procedure:

$$
\text { IvhaJl-t }=\sqrt{I v h a \_J l} \text { or if differently written IvhaJl-t= Ivha_J1 }{ }^{0,5}
$$

Since sizes of dependent variables too did not have normal arrangement of their sizes, dependent variable was previously transformed in the procedure:

$$
\text { IvhaJl-t }=\sqrt{I v h a \_J l} \text { or if differently written IvhaJl-t=Ivha_J1 }{ }^{0,5}
$$

Table 3. Result of multiple regression, size and the significance of the parameters along with nezavisne variables - Model 1

Tabela 3. Rezultat višestruke regresije, veličine i značaj parametara uz nezavisne varijable -

\begin{tabular}{|c|c|c|c|c|c|c|}
\hline Variable & Parameter & $\begin{array}{c}\text { Standard } \\
\text { error }\end{array}$ & t-test & $\begin{array}{c}\text { „p“" } \\
\text { probability }\end{array}$ & $r^{2}$ & VIF \\
\hline constant & 3,64171 & 0,0349 & 104,2110 & 0,0000 & & \\
\hline H50_Jl_st & 0,335319 & 0,0314 & 10,6931 & 0,0000 & 0,2200 & 1,2820 \\
\hline OS_Jl_st & 1,66685 & 0,0437 & 38,1677 & 0,0000 & 0,5978 & 2,4865 \\
\hline OS_L_st & $-0,324375$ & 0,0482 & $-6,7286$ & 0,0000 & 0,6700 & 3,0302 \\
\hline SQ_Dg_Jl_st & $-0,303699$ & 0,0352 & $-8,6256$ & 0,0000 & 0,3813 & 1,6162 \\
\hline ASIN STZ & 0,451424 & 0,0311 & 14,5290 & 0,0000 & 0,2054 & 1,2585 \\
\hline 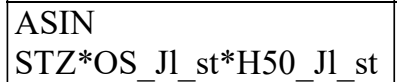 & $-0,0850408$ & 0,0301 & $-2,8223$ & 0,0048 & 0,2171 & 1,2772 \\
\hline ASIN STZ*OS_L_st & $-0,0659479$ & 0,0320 & $-2,0599$ & 0,0394 & 0,3000 & 1,4286 \\
\hline OS_Jl_t*H50_Jl_st & 0,117261 & 0,0269 & 4,3551 & 0,0000 & 0,1968 & 1,2450 \\
\hline OS_Jl_st*SQ_Dg_Jl_st & $-0,155427$ & 0,0300 & $-5,1746$ & 0,0000 & 0,3809 & 1,6153 \\
\hline 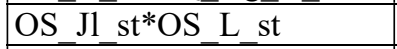 & 0,102135 & 0,0316 & 3,2288 & 0,0012 & 0,3681 & 1,5824 \\
\hline ASIN STZ*H50_Jl_st & $-0,10769$ & 0,0330 & $-3,2663$ & 0,0011 & 0,1652 & 1,1979 \\
\hline \begin{tabular}{|l|} 
OS_Jl_st*OS_L_st*SQ_D \\
g_Jl_st*ASIN STZ
\end{tabular} & $-0,0484716$ & 0,0158 & $-3,0629$ & 0,0022 & 0,2346 & 1,3065 \\
\hline
\end{tabular}
Model 1

After factor regression after "Stepwise-forward" procedure (STATISTICA 7.0) set of independent variables and their interactions which have statistically significant impact to the size of volume increment of the fir (Table 3) after the largest calculated size of the "F" test and which are not mutually collinear (condition: variance inflation factor $V I F<5$ and for every linear zero order coefficient along with independent factor and $r_{i}^{2}<R^{2}$ (Table 3) was designed.

Then the adequacy of transformation of dependent variable was checked through computer program Statgraphic where the original (untransformed) sizes Ivha_Jl were used. Via subsequent procedure of optimization of regression equation, 
via application of BoxCox transformation of dependent variable in the program Statgraphics Centurion optimal size of coefficient $\lambda=0,492$ was calculated. That means that applied transformation in the program Statistica 7.0 was quite sasisfactory $(\lambda=0,5)$.

The result of regression expressed through variances of explained part of varying (Model) real from average sizes of dependent variable and residual variance (Residual), $\mathrm{F}$ by relation of variances and p probability was given in table 4 .

Table 4. Result of regression of multiple regression (Anova table) - the importance of impact of all independent variables to the size of volume increment of fir in the stand of trees - Ivha_Jl (Model 1) along with the application of Box-Cox transformation of dependent variable

Tabela 4. Rezultat regresije višestruke regresije (Anova tabela) - značaj uticaja svih nezavisnih varijabli na veličinu zapreminskog prirasta jele u sastojini - Ivha_Jl (Model 1) uz primjenu Box-Cox transformacije zavisne varijable $\lambda=0,5$, regression model 3 .

\begin{tabular}{|c|r|r|r|r|r|}
\hline The source of variation & $\begin{array}{c}\text { Sum of } \\
\text { square } \\
\text { numbers }\end{array}$ & $\begin{array}{c}\text { Degrees of } \\
\text { freedom }\end{array}$ & Variance & $\begin{array}{c}\text { F- } \\
\text { relation }\end{array}$ & $\begin{array}{c}\text { "P" } \\
\text { probability }\end{array}$ \\
\hline \hline Model & 2838,57 & 12 & 236,548 & 394,37 & 0,0000 \\
\hline Residual & 461,856 & 770 & 0,599813 & & \\
\hline Totally (korigovano) & 3300,43 & 782 & & & \\
\hline
\end{tabular}

Degree of explanation expressed through coefficients of multiple determination: $\mathrm{R}^{2}=$

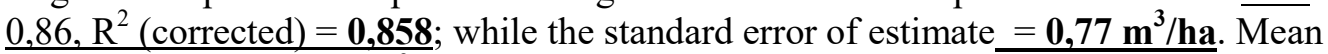
absolute error is $=0,61 \mathrm{~m}^{3} / \mathrm{ha}$, while the final model of regression equation is:

$$
\begin{aligned}
& \text { BoxCox(IVha_Jl) } 3,64171+0,335319^{*} \text { H50_Jl_st }+1,66685^{*} \text { OS_Jl_st - } \\
& 0,324375 * \text { OS_L_st }-0,30 \overline{3} 6 \overline{9} 9 * \mathrm{SQ} \text { Dg_J1_st }+0,451424 * \mathrm{ASIN} \\
& = \\
& \text { STZ - 0,0850408*ASIN STZ*OS_J1_st*H50_J1_st - } \\
& 0,0659479 * A S I N \text { STZ*OS_L_st }+0,117261 * \text { OS_Jl_st*H50_Jl_st } \\
& \text { - 0,155427*OS_Jl_st*SQ_Dg_Jl_st + } \\
& \text { 0,102135*C.OS_J1_t*OS_L_t - 0,10769*ASIN STZ*H50_J1_t - }
\end{aligned}
$$

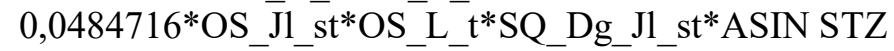

Where: $(\operatorname{model} 1)$

$\operatorname{BoxCox}\left(I v h a \_J l\right)=1+\frac{I v h a \_J I^{0,5}-1}{0,5^{*} 2,59771^{-0,5}}$ and vice versa:

$I v h a \_J l=\left[\operatorname{BoxCox}\left(I V h a \_J l\right){ }^{*} 0,310223484+0,689777\right]^{2}$

Residual arrangement - deviations of real from estimated sizes of volume increment of fir in the stand of trees by comparison with the estimated size of volume increment of fir is depicted at the graph 1. At the graph 2 a relation between real sizes of residuals, presented via circles, and their normally arranged-expected sizes presented via line. Great matching of the arrangement of the real and normally distributed - expected residuals at the graph is in favour of the quality of regression 
equation i.e. the quality of the estimation of the parameters of the equation where one of the conditions is random arrangement of residuals around the estimating equation. Its possible "S-shape" would guide to the possible collinearity of equation parameters i.e. to the uncertainty of the quality of estimation of the equation parameter via t test and sizes of probability , $p$ " (table 90). Random arrangement of residuals within the domain of sizes of all independent variables in the equation should also be expected.

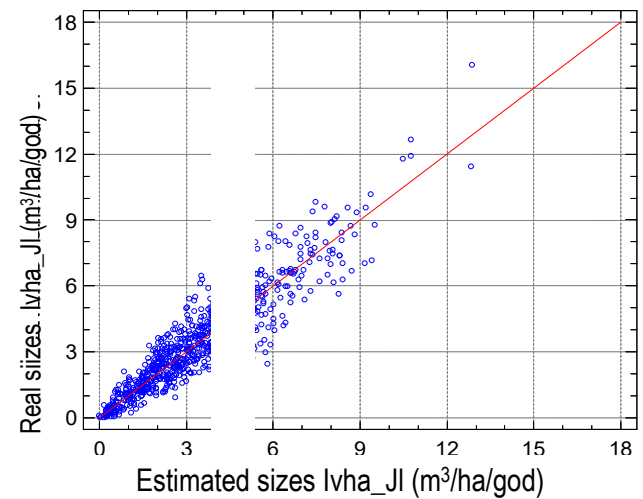

Graph 1: Ratio of real and estimated sizes of volume increment of fir in the stand of trees (Ivha_Jl) per regression equation of the model 1

Grafikon1: Odnos stvarnih $i$ procijenjeih veličina zapreminskog prirasta jele $u$ sastojini (Ivha_Jl) po regresionoj jednačini modela 1

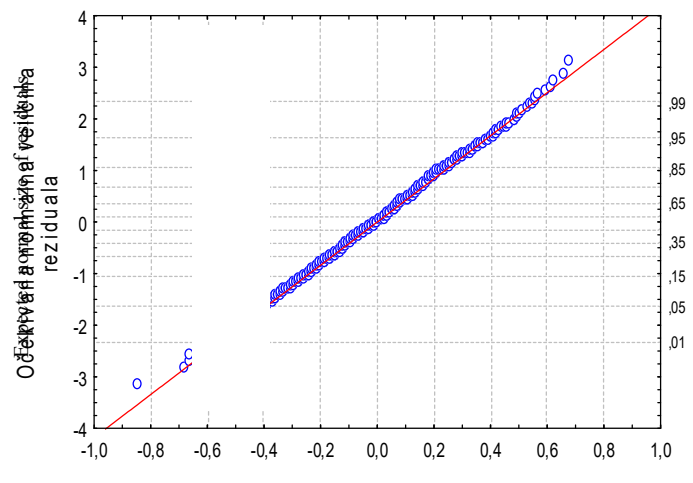

Graph 2: Ratio of real sizes of residuals and and expected normally arranged sizes of residuals per regression equation of model 1

Grafikon 2: Odnos između stvarnih veličina reziduala $i$ očekivanih normalno raspoređenih veličina reziduala po regresionoj jednačini modela 1

From graph 3 on which arrangement of residuals within the domain of independent variable OS_Jl_st (share of fir in the volume of the stand of trees) is represented one can see that there is a systematic negative deviation from the residuals within the domain of change OS_Jl-st, from -2 to approximately $-1,5$ (standardized sizes of share of fir in the volume of the stand of trees) or in the domain of original sizes of share of fir in the volume of trees from 0,0 to $9,0 \%$. 

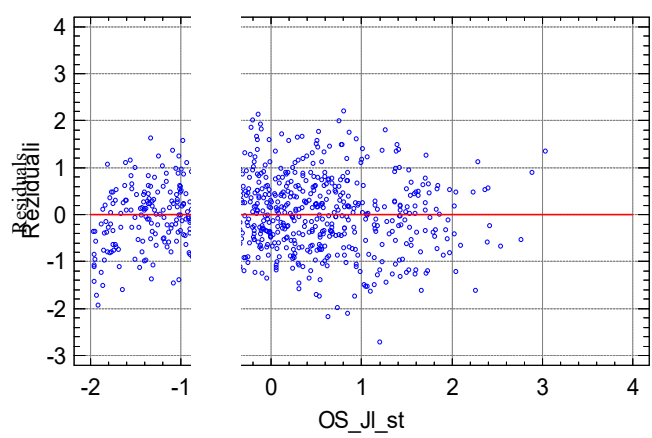

Graph 3: Arrangement of residuals within the domain of change of sizes of independent variable OS_J1_st (reg. model 1)

Grafikon 3: Raspored reziduala u domenu promjene veličina nezavisne varijable OS_Jl_st (reg. model 1)

In the remainder of the domain, the size of this independent variable, residuals are randomly arranged. It means that this regression equation does not provide reliable data for the share of fir in the volume of stand of trees smaller than $10 \%$, i.e. it provides some greater results than the real volume increment. This arrangement of residuals is a consequence of rigid potential transformation of the dependent variable. However, taking into consideration the purpose of use of these results this regression equation can satisfy us fully. Namely, the equation shall be used for the prediction of "normal" size of volume increment of fir in normal and selection stand of trees of beech and fir with spruce where share of fir in the volume of normal stand of trees of fir, spruce and beech should not be smaller than $40 \%$ in any combination of share of beech and spruce because of the amount of the yield.

If we insert original sizes OS_Jl instead of the standardized ones to the obtained regression equation according to the pattern:

$O S_{-} J I_{-} s t=\frac{O S_{-} J I-38,99}{19,88}$, and for other variables their average sizes $(0,00)$ we can

determine the equation of dependence of volume increment of spruce from the share of spruce in the volume of the stand of trees. By increasing share of fir in the in the volume of the stand of trees a share of other species of trees is decreasing. Equation which we can use to calculate the size of Ivha Jl when its share in the volume is increasing along with the simultaneous decrease of share of deciduous trees in the stand of trees would be the following one:

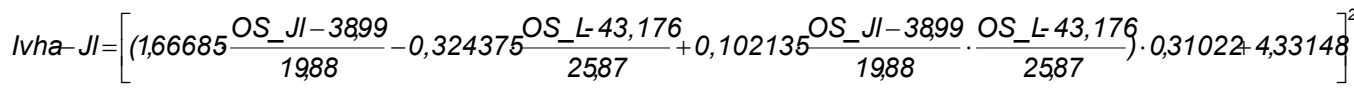




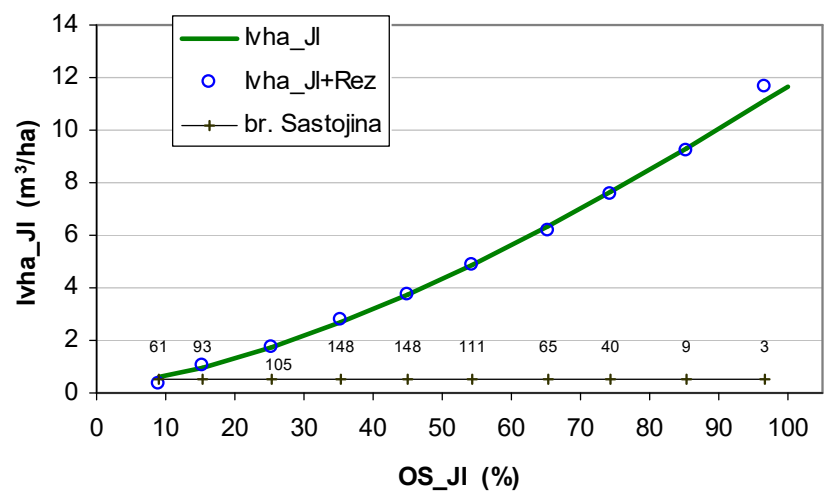

Graph 5: Impact of the share of fir in the volume of stand of trees (OS_Jl) to the size of volume increment of fir (Ivha_Jl)

Grafikon 5: Uticaj udjela jele u zalihi sastojine (OS Jl) na veličinu zapreminskog prirasta jele (Ivha $\mathrm{Jl}$ )
Purusant to this equation sizes of volume increment of fir in the stand of trees (Ivha J1) for different shares of fir in the volume of the stand of trees (OS Jl) were calculated. The calculated sizes are depicted in the graph 5. Real sizes of residuals are grouped per intervals of change OS-J1 of $10 \%$ with enrolled number of residuals (stands of trees) per individual intervals.

Grouped residuals per individual intervals of the size of share of fir mostly do not deviate from the line of estimation of volume increment of fir (Ivha_Jl) except for the smallest and greatest sizes of OS_Jl, below $10 \%$ and over $90 \%$. The character of the impact of the increase of the share of fir in the share of the stand of trees to the size of volume increment of the fir in the stand of trees can clearly be seen from the graph. With the increase of the share of fir the volume increment of fir is progressively increasing. This kind of result is logical if one bears in mind that the increase of fir in the volume of the stand of trees means in average bigger basal area and volume of stand of trees as a whole.

In volumes of mixed stand of trees besides the fir the most important is share in the volume of beech and spruce. With the increase of the share of fir in the volume the share of spruce can decrease but in the greater degree this can happen to the share of beech. Because of the different form of the tree when of the same diameter beech tree shall take much bigger standpoint surface than fir or spruce (PAVLič, 1966., MATIĆ, 1959) and it is completely logical that when the conditions of habitat are the same, the degree of coverage of the ground with crowns of trees in the area of 1 ha there can be more fir then beech and because of that the total volume of the stand of trees is greater. It means that the increase of $1 \%$ in the share of fir in the volume is followed by the increase of $1 \%$ in volume of fir and the basal area too and based on that one can expect progressive increase of the volume increment of fir with the percentile increase of the share of fir in the volume of stand of trees. 

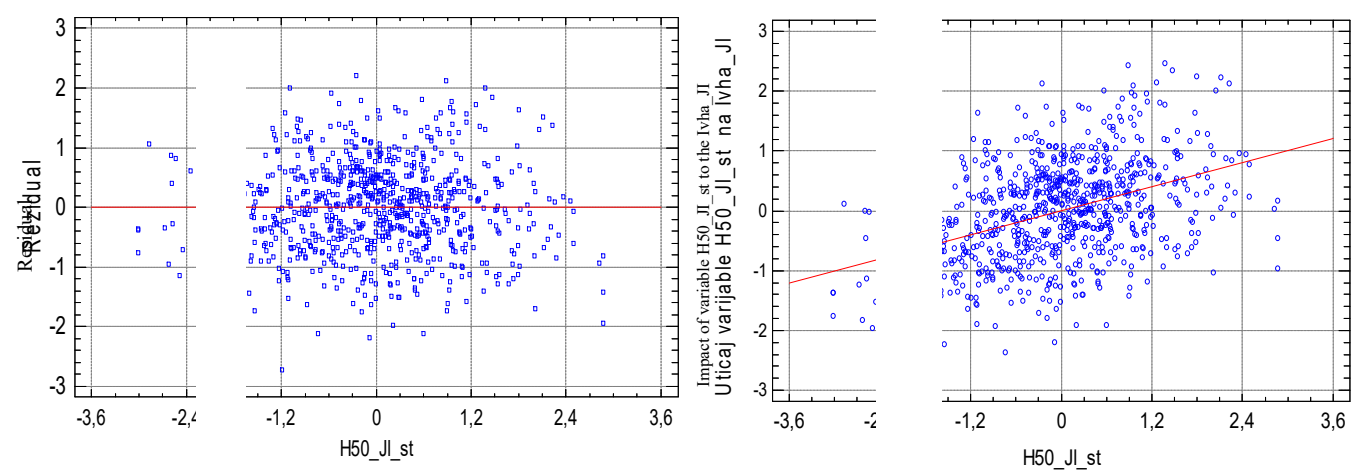

Graph 6: Arrangement of residuals within the domain of change of sizes of independent variable H50_J1_st (reg. model 1)

Grafikon 6: Raspored reziduala $u$ domenu promjene veličina nezavisne varijable H50_Jl_st (reg. model 1)
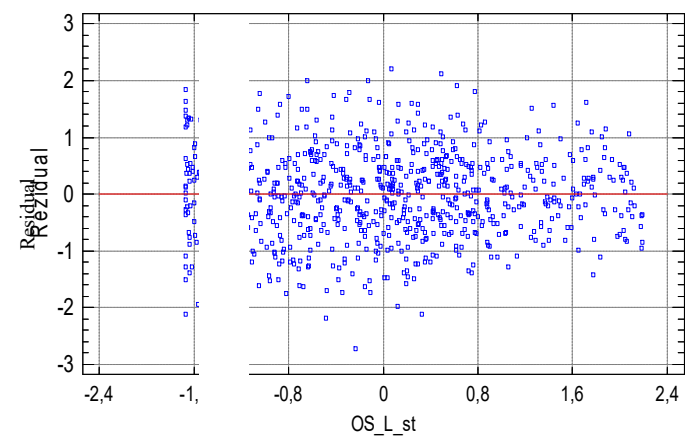

Graph 7: The impact of component H50_Jl_st in the regression model 1 to the size of volume increment of fir (Ivha_Jl)

Grafikon 7: Uticaj komponente H50_Jlst ,u regresionom modelu 1 , na veličinu zapreminskog prirasta jele (Ivha_Jl)
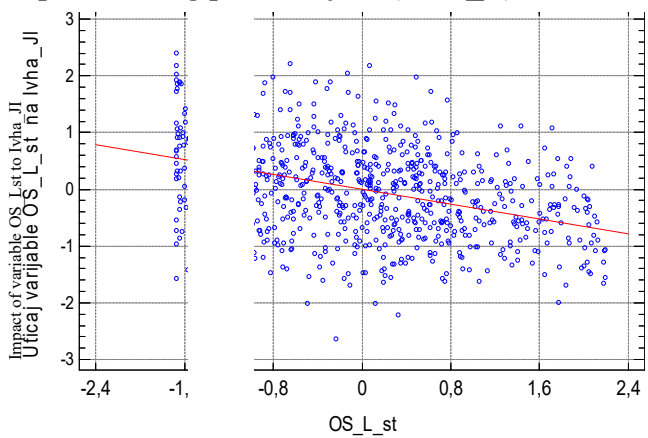

Graph 8: Arrangement of residuals within the domain of change of sizes of independent variable OS_L_st (reg. model 3)

Grafikon 8: Raspored reziduala u domenu promjene veličina nezavisne varijable OS_L_st (reg. model 3)

Graph 9: The impact of component OS_L_st in the regression model 1 to the size of volume increment of fir (Ivha_J1)

Grafikon 9: Uticaj komponente OS_L_st, u regresionom modelu 3, na veličinu zapreminskog prirasta jele (Ivha_Jl)

When it is about other independent variables in the regression equation (model 1) taking into consideration the arrangement of residuals in the domain of changes of their sizes (graphs 6, 8, 10 and 12) one can say that it is satisfactory, i.e. the schedule of the residuals is random in individual parts of the interval of the change of sizes of independent variables. In a similar way, as in the previous case for the share of fir in the volume one can obtain equations that explain their absolute impact on the size of volume increment of fir (Ivha_Jl). Character of those impacts itself can be seen from the graphs 7, 9, 11 and 13, i.e. from these graphs one can see if the increment of some 
of independent variables in the equation influences the increase or decrease of dependent quantities of volume increment of fir (Ivha_Jl)
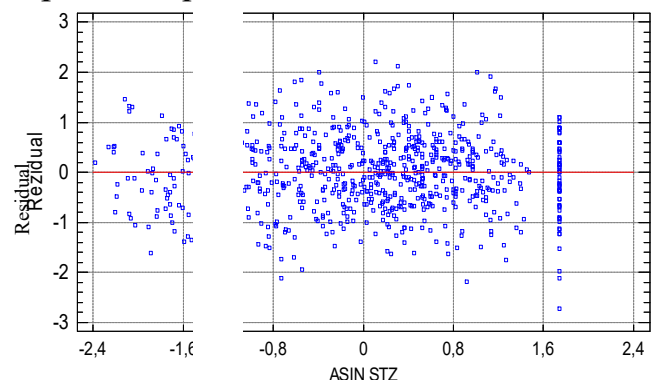

Graph 10: Arrangement of residuals within the domain of change of sizes of independent variable OS_L_st (reg. model 1)

Grafikon 10: Raspored reziduala u domenu promjene veličina nezavisne varijable OS_L_st (reg. model 1)
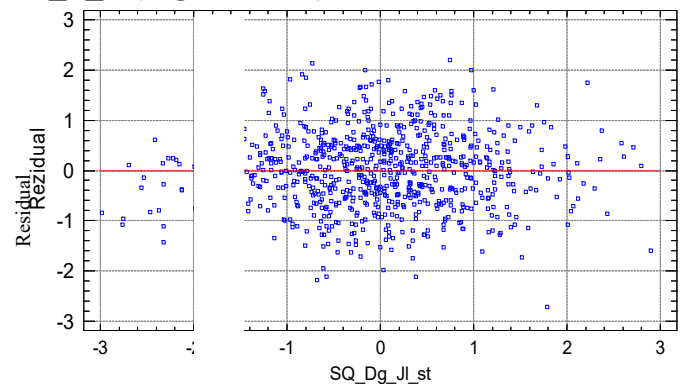

Graph 12: Arrangement of residuals within the domain of change of sizes of independent variable SQ_Dg_Jl_st (reg. model 1)

Grafikon 12: Raspored reziduala u domenu promjene veličina nezavisne varijable $S Q \_D g \_J l$ st (reg. model 1)
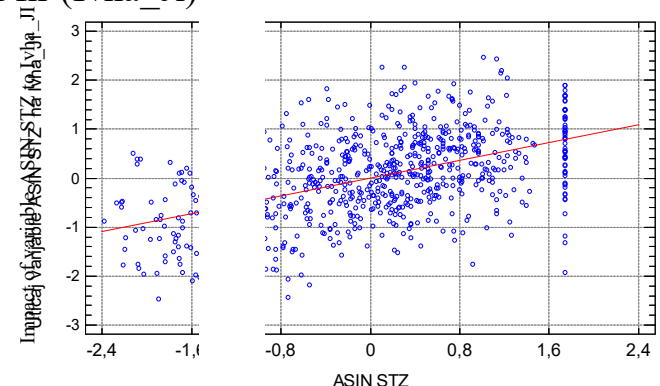

Graph 11: The impact of component OS_L_st in the regression model 1 to the size of volume increment of fir (Ivha_Jl)

Grafikon 11: Uticaj komponente OS L st ,u regresionom modelu 1 , na veličinu zapreminskog prirasta jele (Ivha_Jl)

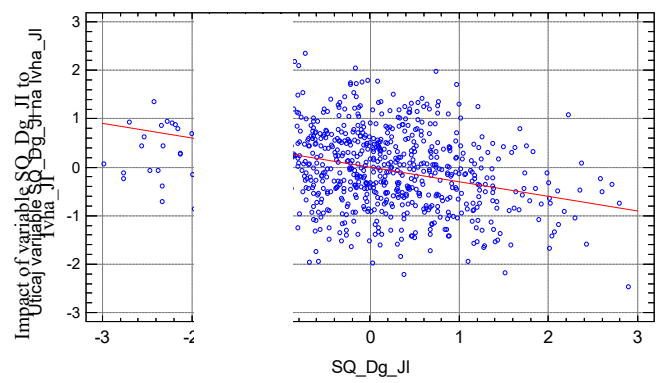

Graph 13: The impact of component SQ_Dg_jl_st in the regression model 1 to the size of volume increment of fir

Grafikon 13: Uticaj komponente $S Q D g$ jl st, u regresionom modelu 1 , na veličinu zapreminskog prirasta jele

By completely the same methodical approach, just by using those variables from which for the most part size of volume increment of the fir depends there was a regression equation determined for as good estimation as possible of volume increment.

\section{Size of current volume increment of spruce share of stand of trees depending on other taxation elements of the share of trees}

In a completely same way - by the same methodical approach as in the previous instance when it was about the volume increment of the fir in the stand of trees a regression equation was determined (model 2 ) for the estimation of volume increment of the spruce in the stand of trees and there is no need to explain the whole procedure in detail. On a place like this just the most important results were displayed 
because of the possibility of further use of regression equations. There were totally 575 stands of trees in the sample in which spruce participated in the volume.

The following tables display variables that are chosen as the ones that have the most influence to the change of size of volume increment of spruce (table 9) - with the note on which variables were used in which model and with the marks of their transformed sizes.

Transformations of independent variables were conducted in a similar way to the previous cases:

$$
S Q_{-} I V_{-} S m=\sqrt{\left.I V h a \_S m\right)}
$$

Square root was taken from variable, medium diameter of spruce in the stand of trees (Dg_Sm) too, and then it was standardized by using the average measurements $(\bar{x})$ and their standard deviations $\left(S_{x}\right)$ given in the table 9 .

Table 9. Markers, meaning and basic statistical indicators of variables from 575 stands of trees containing spruce

Tabela 9. Oznake, značenje i osnovni statistički pokazatelji varijabli iz 575 sastojina u kojima učestvuje smrča

\begin{tabular}{|c|l|c|r|r|r|r|}
\hline $\begin{array}{c}\text { Variable } \\
\text { (Code) }\end{array}$ & Name of the variable & $\begin{array}{c}\text { Physical } \\
\text { quantity }\end{array}$ & $\bar{x}$ & Sx. & Min. & Maks. \\
\hline \hline Ivha_Sm & $\begin{array}{l}\text { Current volume } \\
\text { increment of spruce }\end{array}$ & $\mathrm{m}^{3} / \mathrm{ha}$ & 2,20 & 1,94 & 0,01 & 15,1 \\
\hline H50_Sm & $\begin{array}{l}\text { Average height of } \\
\text { spruce tree whose } \\
\text { diameter is 50 cm }\end{array}$ & $\mathrm{m}$ & 27,74 & 20,73 & 36,5 & 2,7 \\
\hline STZ & $\begin{array}{l}\text { Degree of coverage } \\
\text { of ground with } \\
\text { crowns of trees }\end{array}$ & $\%$ & 86,66 & 12,37 & 44,7 & 100,0 \\
\hline Dg_Sm & $\begin{array}{l}\text { Medium diameter of } \\
\text { spruce }\end{array}$ & $\mathrm{cm}$ & 30,56 & 9,83 & 5,0 & 64,9 \\
\hline OS_Sm & $\begin{array}{l}\text { Share of spruce in } \\
\text { the volume of the } \\
\text { stand of trees }\end{array}$ & $\%$ & 25,24 & 19,70 & 0,01 & 100,0 \\
\hline OS_L & $\begin{array}{l}\text { Share of deciduous } \\
\text { trees in the volume } \\
\text { of the volume of } \\
\text { stand of trees }\end{array}$ & $\%$ & 34,61 & 22,21 & 0,01 & 95,2 \\
\hline
\end{tabular}

SQ_Dg_S $=\sqrt{D g \_S m}$; and then after the formula 1:

$S Q_{-} D g_{-} S_{-} s t=\frac{S Q_{-} D g_{-} S-5,45649}{0,88708}$;

Square root was taken from basal area of the spruce in the stand of trees too (GHA_Sm) and then it was standaridized. 
Regresion models for assesment of the volume increment of the fir, beech and spruce in forests of beech, fir and spruce on limestone in Federation of Bosnia and Herzegovina

SQ_GHA_Sm $=\sqrt{G H A \_S m}$; and then after the formula 1:

$S Q_{-} G H A_{-} S_{-} s t=\frac{S Q_{-} G H A_{-} S m-4,62537}{1,96228}$;

Table 10. Marks of original and transformed variables and basic statistical indicators of variables from 575 stands of trees of which spruce is part (for regression model 2)

Tabela 10. Oznake originalnih i transformisanih varijabli $i$ osnovni statistički pokazatelji varijabli iz 575 sastojina u kojima učestvuje smrča (za regresioni model 2)

\begin{tabular}{|c|l|r|r|r|r|}
\hline $\begin{array}{c}\text { Mark of } \\
\text { the } \\
\text { variable }\end{array}$ & Marks of transformed variables & $\bar{x}$ & \multicolumn{1}{|c|}{ Sx. } & \multicolumn{1}{c|}{ Min. } & \multicolumn{1}{c|}{ Max. } \\
\hline \hline Ivha_Sm & SQ_Iv_Sm & 1,35 & 0,62 & 0,00 & 3,88 \\
\hline \multirow{2}{*}{ STZ } & arcsinSTZ/100 & 1,11 & 0,25 & 0,46 & 1,57 \\
\cline { 2 - 6 } & ASIN STZ & 0,00 & 1,00 & $-2,53$ & 1,82 \\
\hline OS_L & OS-L_st & 0,00 & 1,00 & $-1,56$ & 2,73 \\
\hline H50_Sm & H50_Sm_st & 0,00 & 1,00 & $-2,57$ & 3,20 \\
\hline \multirow{2}{*}{ Dg-Sm } & SQ_Dg_S & 5,46 & 0,89 & 2,24 & 8,06 \\
\cline { 2 - 6 } & SQ_Dg_S_st & 0,00 & 1,00 & $-3,63$ & 2,93 \\
\hline \multirow{2}{*}{ OS_Sm } & SQ_OS_Sm & 4,63 & 1,96 & 0,00 & 10,00 \\
\cline { 2 - 6 } & SQ_OSS_st & 0,00 & 1,00 & $-2,36$ & 2,74 \\
\hline
\end{tabular}

Variable STZ - degree of coverage of ground with crowns of trees was transformed in the same manner as in the previous instances by usining equation 23 : $\operatorname{asin}(S T Z / 100)=\arcsin \frac{S T Z}{100}$,

then the sizes were standardized upon the formula 1 by using the average size and standard deviation of variable asinSTZ/100 (table 10).

Variables: altitude (HEIGHT), share of deciduous trees in the volume of stand of trees (OS_L) and average height of spruce tree whose diameter is $50 \mathrm{~cm}$ (H50_Sm) are standardized after the formula 1.

\section{Size of current volume increment of beech share of stand of trees depending on other taxation elements of the share of trees}

In comparison to equations for estimation of volume increment of fir and spruce, equations for the estimation of volume increment of beech are different only in the manner of the transformation of dependent variable - volume increment of the beech (Ivha-Bk) and independent variables that are the most influential, share of beech in the volume of stand of trees (OS_Bk) in regression equation model 3. Namely, the character of dependence of volume increment of beech in the volume of the stand of trees (OS_Bk) is different in comparison to the dependence of volume increment of fir or spruce from their share in the volume of the stand of trees, so in this case the following log transformation was used for the volume increment of the beech:

$$
x_{T}=L n(x) ; \ldots \ldots \ldots \ldots . . .(4) ; \quad \text { tj. } \quad L n_{-} I v_{-} B k=L n\left(I v h a_{-} B k\right) .
$$


Square root was taken from mediums diameter of spruce in the stand of trees (Dg_Sm) too, and then they were standardized by using the average measurements ( $\bar{x}$ ) and their standard deviations $\left(S_{x}\right)$ given in the table 11 .

$S Q_{-} D g_{-} B k=\sqrt{D g \_B k} ;$ and then after the formula $1:$

$S Q_{-} D g_{-} B k_{-} s t=\frac{S Q_{-} D g_{-} B k-4,744}{0,7614}$;

Variable STZ - degree of coverage of ground with crowns of trees was transformed in the same manner as in the all previous instances and variables: altitude (HEIGHT), share of fir in the volume of stand of trees (OS_Jl) and average height of the beech tree whose diameter is $50 \mathrm{~cm}\left(\mathrm{H} 50 \_\mathrm{Bk}\right)$ are standardized upon the formula 1 as in the previous cases.

Table 11 displays variables that are chosen as the ones that have the most influence to the change of size of volume increment of beech - with the note on which regression model was used in which variables and with the marks of their transformed sizes

Table 11. Markers, meaning and basic statistical indicators of variables from 575 stands of trees containing beech

Tabela 11. Oznake, značenje i osnovni statistički pokazatelji varijabli iz 755 sastojina u kojima učestvuje bukva

\begin{tabular}{|c|l|c|c|c|c|c|}
\hline $\begin{array}{c}\text { Variable } \\
\text { (Code) }\end{array}$ & \multicolumn{1}{|c|}{ Name of the variable } & $\begin{array}{c}\text { Physical } \\
\text { quantity }\end{array}$ & $\overline{\boldsymbol{X}}$ & Sx. & Min. & Maks. \\
\hline \hline Ivha_Bk & $\begin{array}{l}\text { Current volume increment } \\
\text { of spruce }\end{array}$ & $\mathrm{m}^{3} / \mathrm{ha}$ & 2,76 & 1,52 & 0,01 & 8,84 \\
\hline H50_Bk & $\begin{array}{l}\text { Average height of spruce } \\
\text { tree whose diameter is 50 } \\
\mathrm{cm}\end{array}$ & $\mathrm{m}$ & 26,55 & 2,32 & 20,18 & 33,38 \\
\hline VISINA & Altitude of the stand of trees & $\mathrm{m}$ & 1095 & 206,78 & 570 & 1585 \\
\hline STZ & $\begin{array}{l}\text { Degree of coverage of } \\
\text { ground with crowns of } \\
\text { trees }\end{array}$ & $\%$ & 87,72 & 11,84 & 32,62 & 100,00 \\
\hline Gha_Bk & $\begin{array}{l}\text { Basal area of beech in the } \\
\text { stand of trees }\end{array}$ & $\mathrm{m}^{2} / \mathrm{ha}$ & 12,18 & 6,26 & 0,11 & 36,46 \\
\hline Dg_Bk & Medium diameter of beech & $\mathrm{cm}$ & 23,09 & 7,73 & 6,08 & 64,43 \\
\hline OS_Bk & $\begin{array}{l}\text { Share of beech in the } \\
\text { volume of the stand of } \\
\text { trees }\end{array}$ & $\%$ & 39,86 & 22,34 & 0,04 & 95,00 \\
\hline OS_J1 & $\begin{array}{l}\text { Share of fir in the volume } \\
\text { of the stand of trees }\end{array}$ & $\%$ & 37,75 & 20,26 & 0,00 & 96,42 \\
\hline
\end{tabular}

Marks of original and transformed variables and basic statistical indicators of transformed variables from 755 stand of trees of which beech is a part are given in the table 12. 
Table 12. Marks of original and transformed variables and basic statistical indicators of variables from 575 stands of trees of which beech is a part (for regression model 5 and 6)

Tabela 12. Oznake originalnih $i$ transformisanih varijabli $i$ osnovni statistički pokazatelji varijabli iz 755 sastojine u kojima učestvuje bukva (za regresioni model 5 i 6)

\begin{tabular}{|c|l|c|c|c|c|}
\hline $\begin{array}{c}\text { Mark of } \\
\text { the } \\
\text { variable }\end{array}$ & Marks of transformed variables & $\bar{x}$ & Sx. & Min. & Max. \\
\hline \hline H50_Bk & H50_Bk_st & 0,00 & 1,000 & $-2,7474$ & 2,942 \\
\hline VISINA & Nd_Vis_tr & 0,00 & 1,000 & $-2,5415$ & 2,367 \\
\hline \multirow{2}{*}{ STZ } & arcsinSTZ/100 & 1,133 & 0,2539 & 0,3322 & 1,571 \\
\cline { 2 - 5 } & ASIN STZ & 0,00 & 1,000 & $-3,1524$ & 1,725 \\
\hline GHA_Bk & Ln_GHA_Bk & 2,262 & 0,8866 & $-2,1636$ & 3,596 \\
\hline \multirow{2}{*}{ Dg_Bk } & SQ_Dg_Bk & 4,744 & 0,7614 & 2,4663 & 8,027 \\
\cline { 2 - 6 } & SQ_Dg_Bk_st & 0,00 & 1,000 & $-2,9922$ & 4,311 \\
\hline OS_Bk & Ln_OS_Bk & 3,388 & 1,0273 & $-3,3104$ & 4,554 \\
\hline OS_Jl & OS_Jl_st & 0,00 & 1,000 & $-1,8635$ & 2,896 \\
\hline
\end{tabular}

\section{Regression model 3}

In the forming of regression equation 3 for explanation of changes of size of volume increment of beech in the stand of trees those taxation elements which we can assume in advance were used during formation of normal state of selection stand of trees. Those are: share of beech in the in the volume of the stand of trees (OS_Bk), average height of beech trees whose diameter is $50 \mathrm{~cm}$ (H50_Bk), medium diameter of beech (Dg_Bk), degree of coverage of ground with crowns of trees (STZ) and share of fir in the volume of the stand of trees (OS_Jl).

Obtained degree of explanation expressed through coefficients of multiple determination: $\underline{\mathbf{R}^{2}=\mathbf{0 , 9 0 8}} ; \underline{\mathrm{R}}^{2}$ (corrected) $=0,907$; while the standard error of estimate is Ln_Iv_Bk $=0,27 \mathrm{~m}^{3} / \mathrm{ha}$, and the calculated error of estimate is Ivha_Bk = $0,77 \mathrm{~m}^{3} / \mathrm{ha}$.

Model of regression equation 3 is:

$$
\begin{aligned}
& \text { Ln_Iv_Bk }=-2,10406+0,132926 * A S I N \quad \text { STZ }+0,100495 * H 50 \_B k \_s t \quad- \\
& 0,0642515 * \text { SQ_Dg_Bk_st }+0,845395 * \text { Ln_OS_Bk - } \\
& -0,0357713 * \text { OS_Jl } t * \text { SQ_Dg_Bk_st } \\
& 0,0202162 * \text { H50_Bk_st*SQ_Dg_Bk_st }+0,0204286^{*} \mathrm{OS} \text { J J _t }{ }^{*} \mathrm{Ln}
\end{aligned}
$$

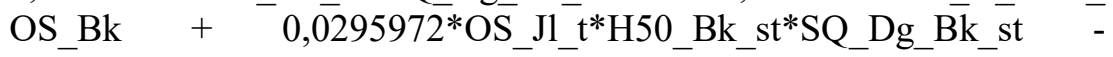

$$
\begin{aligned}
& \text { 0,00791337*ASIN STZ*H50_Bk_st*Ln_OS_Bk- } \\
& -0,00745845 * \text { ASIN STZ*OS_J1_t*H50_Bk_st*Ln_OS_Bk }
\end{aligned}
$$

Where: Ivha_Bk $=e^{\text {Ln_Iv_Bk}} ;(e=2,718281828)$.

Arrangement of residuals around the calculated sizes Ln_Iv_Bk is depicted in the graph 18. 


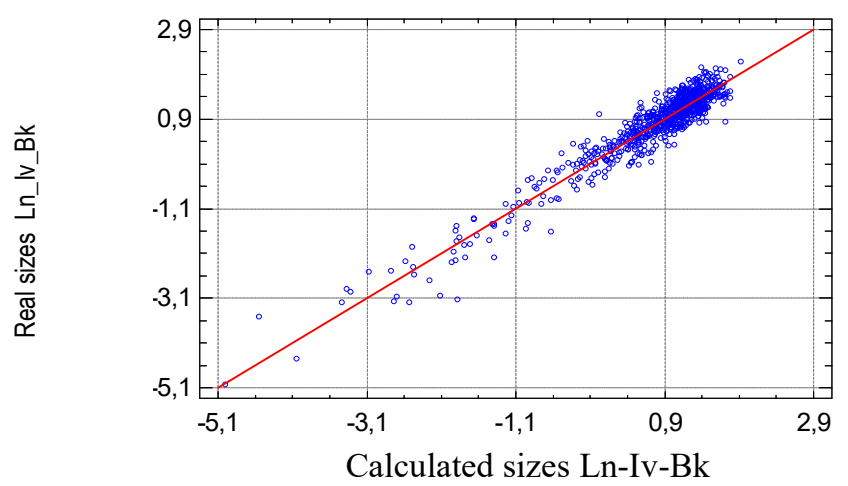

Graph 14: Relationship between the real and calculated size Ln_Iv_Bk with the arrangement of residuals around the line of estimation ( reg. model 3)

Grafikon 14: Odnos stvarne i izračunate veličine $L n \_I v \_B k$ sa rasporedom reziduala oko linije procjene

(reg. model 3)

\section{Size of current volume increment of mixed stands of trees of beech and fir with spruce}

In the used sample of this work, in woods of beech and fir with spruce in which all those 3 species of trees were included, there were 459 stands of trees. Average relative site classes were 2,9 for fir, 3,2 for spruce and 3,2 for beech at average share of fir in the volume of the stand of trees in the amount of $39,4 \%$, spruce of $23,8 \%$ and beech of $32,5 \%$. Rest of the volume are made of noble deciduous trees in the amount of 3,5\% and other deciduous trees with about $0,9 \%$. If we would take into consideration heights of trees whose diameter is $50 \mathrm{~cm}$ which would match upper site classes and average sizes of other taxation elements of these stands of trees, size of annual volume increment of pure fir stand of trees would be around 11,64 $\mathrm{m}^{3} / \mathrm{ha}$, size of pure volume increment of spruce stand of trees would be around $8,8 \mathrm{~m}^{3} / \mathrm{ha}$, while the volume increment of pure beech stand of trees would be around $4,93 \mathrm{~m}^{3} / \mathrm{ha}$. These data were calculated using determined equations for calculating the size of current volume increment of fir, spruce and beech (from models 3, 5 and 7). 
Regresion models for assesment of the volume increment of the fir, beech and spruce in forests of beech, fir and spruce on limestone in Federation of Bosnia and Herzegovina

Table 13. Volume increment of mixed stands stand of fir, spruce and beech trees on the different site classes with the ratio of fir $50 \%$, spruce $20 \%$ and beech of $30 \%$ at the end of shift of 10 years.

Tabela 13. Zapreminski prirast mješovitih prebornih sastojina jele smrče i bukve na različitim bonitetima staništa sa udjelom jele u zalihi od $50 \%$, smrče $20 \%$ i bukve od 30\%, na kraju turnusa od 10 godina.

\begin{tabular}{|c|c|c|c|c|c|c|c|c|c|}
\hline 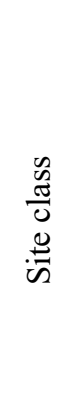 & & 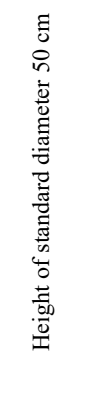 & 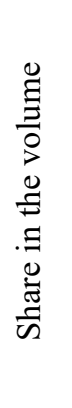 & 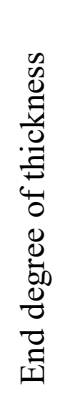 & 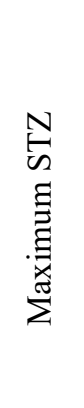 & 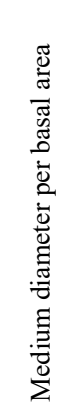 & 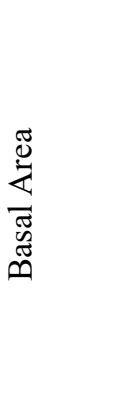 & 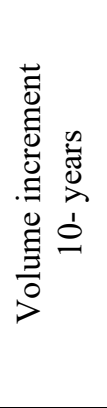 & 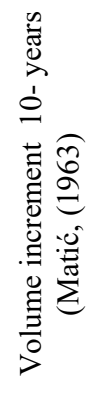 \\
\hline Rel. & & $\mathrm{m}$ & $\%$ & $\mathrm{~cm}$ & $\%$ & $\mathrm{~cm}$ & $\mathrm{~m}^{2} / \mathrm{ha}$ & $\mathrm{m}^{3} / \mathrm{ha}$ & $\mathrm{m}^{3} / \mathrm{ha}$ \\
\hline \multirow{4}{*}{ II } & fir & 30,3 & 50 & 75 & \multirow{3}{*}{89,8} & 24,5 & 16,06 & 52,7 & 49,0 \\
\hline & spruce & 32,6 & 20 & 75 & & 24,7 & 6,35 & 20,2 & 17,0 \\
\hline & beech & 30,1 & 30 & 75 & & 19,3 & 10,2 & 26,4 & 20,0 \\
\hline & $\begin{array}{c}\text { all } \\
\text { types }\end{array}$ & & & & & & 32,6 & 99,3 & 86,0 \\
\hline & fir & 26,8 & 50 & 70 & & 22,4 & 15,27 & 46,1 & 44,0 \\
\hline & spruce & 28,6 & 20 & 70 & 88,5 & 22,5 & 5,9 & 19,6 & 16,0 \\
\hline III & beech & 26,8 & 30 & 70 & & 19 & 9,5 & 21,6 & 17,0 \\
\hline & $\begin{array}{c}\text { all } \\
\text { types }\end{array}$ & & & & & & 30,7 & 87,3 & 77,0 \\
\hline & fir & 23,4 & 50 & 60 & & 21,0 & 14,2 & 37,7 & 36 \\
\hline & spruce & 24,7 & 20 & 60 & 86,0 & 20,5 & 5,5 & 15,2 & 14 \\
\hline IV & beech & 23,5 & 30 & 60 & & 17,2 & 8,9 & 16,3 & 14 \\
\hline & $\begin{array}{c}\text { all } \\
\text { types }\end{array}$ & & & & & & 28,6 & 69,4 & 64,0 \\
\hline
\end{tabular}

Table 13 represents calculated sizes of taxational elements of three mixed selection stand of trees of fir, spruce and beech of the same share in the volume of fir, spruce and beech and for average second, third and fourth site class of these species of trees and for the state at the end of shift of 10 years.

Shift of logging of 10 years was chosen for the reason because this length of shift was applied in the forests of Bosnia and Herzegovina. Recommended ratio of mixture for better habitats of fir and beech forests with spruce, with the share of fir in the volume of $50 \%$ spruce $20 \%$ and beech $30 \%$ was chosen. This ratio of mixture of 
types of trees is close to average in the sample whose share of conifers - fir and spruce together $(64.6 \%)$.

In stands of trees in which all three species of trees participated of those who were II of average site class, average altitude (m.n.v.) was $987 \mathrm{~m}$. In the stands of trees of III site class 1086 m.n.v. and in stands of trees of IV average site class habitat 1280 m.n.v.

In the end right column volume increment is displayed according to the results of MATIC (1963), i.e. data on the expected ten-year volume increment. Data are approximate taking into consideration that it is unknown which degree of coverage of ground with crowns of trees (degree of composition) and which medium diameter of the tree should be input sizes for the tables of volume increment taking into consideration that in MATIĆ'S research a taxation threshold of $10 \mathrm{~cm}$ was used while in these researches that threshold was $5 \mathrm{~cm}$. It can only be estimated based the size of the basal area, determined normal composition for the combination of the ratio of mixture and site class for these types of trees.

From these results it is quite clear that the size of the yield in mixed selection stands of trees of fir, spruce and beech can be significantly increased by increasing the ratio of spruce and especially of fir at the expense of beech.

\section{CONCLUSIONS - Zaključci}

MATIĆ (1959) conducted very similar researches within these forests. His sample encompassed the stands of trees on silicate rocks in the $\mathrm{BiH}$. $\mathrm{He}$ also conducted researches of change of sizes of volume increment of these forest stands if trees depending on other taxation elements of stands of trees.

If we insert average (the same) sizes of independent variables (of the same site class and the share of species of trees in the stand of trees of approximately the same degree of coverage of ground with crowns of trees ) to the regression models of this paper and regression models made by MATIĆ (1959) we would get the results that indicate that in the average volume increment in beech and fir woods with spruce that are located on limestone and dolomites today is bigger for around $1 \mathrm{~m}^{3} /$ ha annually in comparison to more than 50 years ago (table 13) when the data were collected for MATIĆ'S research in the beech and fir woods with spruce, on different grounds and bedrocks. We do not know clear reasons for that.

MATIC (1959) predicted the increase of volume increment because at the time of his research in these forests trees growing in the conditions of old-growth forest, with little length and volume of the crowns of trees were significantly present.

It is possible that 50 years later there occurred a significant change in the volume of crowns of trees due to the intensive management of these forests but this measuring of crowns of trees did not occur in the in the $\mathrm{BiH}$ in recent time so that one could be absolutely certain.

Determined increase of volume increment in these forests is a possible consequence and the increase of $\mathrm{CO}_{2}$ in the atmosphere in last decades. HASENAUER (2006) emphasizes that in the several last decades there was a significant change in 
conditions of forest trees in the Europe. In support to that he states researches of other authors (KENKA 1991, 1993; SPICKERA et al 1996; KARJALAINENA et al 1999). He states that one positive trend in the increase of the productivity of habitat in southern parts of northern Europe, central Europe and some parts of southern Europe.

\section{REFERENCES - Literatura}

LOJO, A. (2013): Climat Impact on Volume Increment of the Forests of Beech, Fir and Spruce on Limestone and Dolomite in Federation of Bosna and Herzegovina -Uticaj klime i orografskih faktora na zapreminski prirast u šumama bukve i jele sa smrčom na krečnjacima i dolomitima u Federaciji Bosne i Hercegovine. Radovi Šumarskog fakulteta Univerziteta u Sarajevu, knjiga 43 sveska 1, str1 -25. Sarajevo

BOZALO, G. (1980): Zavisnost veličine zapreminskog prirasta bukve u čistim bukovim sastojinama i mješovitim sastojinama bukve, jele i smrče na području Bosne od veličine njene zapremine i drugih taksacionih elemenata sastojine. Radovi Šumarskog fakulteta i Instituta za šumarstvo u Sarajevu, knjiga 24. sv 2. Sarajevo

BOZALO, G. (1985): Indikatorska vrijednost krivulja visina stabala bukovih sastojina pri produkcionom diferenciranju staništa Bukve na području Bosne. Šumarstvo i prerada drveta. str. $157-167$. Sarajevo.

BURGER H (1950): Holz, Blattmenge und Zuwachs X. Die Buche. Mitt. der Schweiz. Anstalt für d. Forstl. Versuchswes 26:419-468

BURGER H (1951): Holz, Blattmenge und Zuwachs XI. Die Tanne. Mitt. der Schweiz. Anstalt für d. Forstl. Versuchswes 27:247-286

Burger H (1952): Holz, Blattmenge und Zuwachs XII. Fichten im Plenterwald. Mitt. der Schweiz. Anstalt für d. Forstl. Versuchswes 28:109-156

DRINIĆ, P. (1972): Dinamika rastenja i prirašćivanja bukve, jele i smrče u najvažnijim tipovima bukovo-jelovih šuma na Igmanu. Radovi Šumarskog fakulteta i Instituta za šumarstvo u Sarajevu, knj. 17, sv. 4-6.

DRINiĆ, P. (1976): Dinamika rastenja jele i smrče u najvažnijim tipovima četinarkih šuma na Igmanu. Radovi Šumarskog fakulteta i Instituta za šumarstvo u Sarajevu, knj. 19, sv. 1.

DRINIĆ, P., MATIĆ, V., PAVLIČ, J., PROLIĆ, N., STOJANOVIĆ, O., VUKMIROVIĆ, V. (1980): Tablice taksacionih elemenata visokih i izdanačkih šuma u SR Bosni i Hercegovini. Šumarski fakultet Univerziteta u Sarajevu. Posebna izdanja br. 13. Sarajevo.

HASENAUER, H. (2006): Sustainable Forest Management: Growt Models for Europe. Springer, Berlin, 398 pp.

MATiĆ,V. (1959): Taksacioni elementi prebornih šuma jele, smrče i bukve na području Bosne, Radovi Šumarskog fakulteta i Instituta za šumarstvo i drvnu industriju u Sarajevu, br 4. Sarajevo. 
MATIĆ,V. (1963): Osnovi i metod utvrđivanja normalnog sastava za preborne sastojine jele, smrče, bukve i hrasta na području Bosne. Radovi Šumarskog fakulteta i Instituta za šumarstvo i drvnu industriju u Sarajevu. God. VIII. Br. 8.

MATIĆ,V. (1980): Prirast i prinos šuma. Univerzitet u Sarajevu. Sarajevo.

PAVLiČ, J. (1966): Prirast stabala u zavisnosti od veličine krošnje i od njegovog položaja u sastojini. Radovi Šumarskog fakulteta i Instituta za šumarstvo u Sarajevu, knj. 10, sv. 1.

SOKAL, R.R., ROHLF, F.J.(1995): Biometry The Principles and Practice of Statistics in Biological Research. Third edition. W. H. Freeman and Company. New York.

STATISTICA - TEXT BOOK (2008): -Stat Soft, Inc. 1984-2008.

http://www.statsoft.com/textbook/stathome.html.

\section{SAŽETAK}

U radu su prikazani rezultati istraživanja veličina zapreminskog prirasta glavnih vrsta drveća, jele, bukve i smrče unutar mješovitih šuma bukve, jele i smrče na krečnjacima i dolomitima u Federaciji Bosne i Hercegovine (FBiH).

Šume bukve i jele sa smrčom predstavljaju najvažniji dio šumskih resursa u BiH. Prema LOJO (2013) oko 371000 ha, ovih šuma nalazi se na krečnjacima dolomitima i u največoj mjeri imaju prebornu strukturu. Poznavanje zakonitosti promjena veličina zapreminskog prirasta prebornih sastojina je neophodan uslov za kvalitetno planiranje šumarske proizvodnje. U radu su istražene promjene veličina zapreminskog prirasta posebno za vrste drveča jelu, smrču i bukvu, unutar mješovitih sastojina ovih vrsta drveća. Uzorak za istraživanja su premjerene primjerne plohe iz 799 mješovitih sastojina većih od 40 ha, snimljene tokom 11 godina, prilikom izrade šumskogospodarskih osnova. U uzorak su odabrane sastojine u kojima su izvršena kontrolna snimanja radi pouzdanosti podataka. Utvrđeno je više regresionih modela za procjenu veličina zapreminskog prirasta jele, smrče i bukve, i to po dva modela za svaku vrstu drveća. Modeli koji služe za procjenu veličine zapreminskog prirasta mješovite šume u optimalnom - normalnom stanju i modeli koji služe za što preciznije određenje zapreminskog prirasta kada su poznate veličine više nezavisnih faktora koji utiču na promjenu veličine zapreminskog prirasta. U ovom radu je istraživana zavisnost promjene zapreminskog prirasta od: boniteta staništa, izraženog preko prosječne visine stabala prečnika $50 \mathrm{~cm}$, udjela vrste drveća u zalihi sastojine, stepena prekrivenosti zemljišta krošnjama stabala, srednjeg prečnika stabala u sastojini izračunatog na bazi temeljnice vrste drveća i udjela lišćara u zalihi sastojine. Za precizniji model korišteni su kao nezavisni faktori: veličina temeljnice vrste drveća $u$ sastojini, i prosječna nadmorska visina sastojine.

Corresponding author: Ahmet Lojo; Faculty of Forestry University Sarajevo; Zagrebačka 20, 71000 Sarajevo, Bosna\&Herzegovina; e-mail address: a.lojo@sfsa.unsa.ba 